\title{
Basal Cell Proliferation Induced by Chlormadinone Acetate Suggests Stem Cell Transformation of Prostatic Cells
}

\author{
Teiichiro Aoyagi*, Issei Takizawa, Isao Kuroda \\ Department of Urology, Tokyo Medical University Ibaraki Medical Center, Ibaraki, Japan \\ Email: ${ }^{\star}$ aoyagite@toyo-med.ac.jp
}

How to cite this paper: Aoyagi, T., Takizawa, I. and Kuroda, I. (2018) Basal Cell Proliferation Induced by Chlormadinone Acetate Suggests Stem Cell Transformation of Prostatic Cells. Journal of Cancer Therapy, 9, 268-273.

https://doi.org/10.4236/jct.2018.93024

Received: January 26, 2018

Accepted: March 16, 2018

Published: March 19, 2018

Copyright $\odot 2018$ by authors and Scientific Research Publishing Inc. This work is licensed under the Creative Commons Attribution International License (CC BY 4.0).

http://creativecommons.org/licenses/by/4.0/

(c) (i) Open Access

\begin{abstract}
Introduction and Objective: Epithelial to Mesenchymal transition (EMT) at the first hormonal therapy is thought to play an essential role in obtaining castrate resistance for hormone naïve prostate cancer. So we studied EMT of prostatic cells after exposing various hormonal agents using transurethral resection (TUR) specimens. Patients and Methods: TUR specimens without hormonal use (4 cases), specimens after three weeks of chlormadinone acetate (CMA) (9 cases), specimens after average six months of dutasteride ( 3 cases), and specimens two weeks after initial use of degarelix ( 3 cases) were studied using $\mathrm{HE}$ and immunohistochemical staining with prostate specific antigen (PSA), prostatic stem cell markers such as CD44, CD117, CD133 and Vimentin. Results: Specimens treated with CMA showed acinar dilatation and atrophy of glandular cells. Specimens treated with dutasteride showed marked decrease of gland and specimens treated with degarelix showed decrease of glandular cells. PSA was stained all of the prostatic glandular cells in all specimens. CD44 was stained at basal cells in normal prostatic tissue without hormones, however in hormone treated specimens, basal cells elongate and some glandular cells were also stained by CD44, especially in CMA treated specimens. Only small numbers of infiltrating cells in interstitial tissue positively stained with CD 117 and CD 133 in all specimens. Vimentin was stained in all mesenchymal interstitial cells. Conclusion: Elongation of basal cells and increased sensitivity to CD44 in glandular cells, especially treated with CMA, were thought to the result of EMT of prostatic glandular cells.
\end{abstract}

\section{Keywords}

Stem Cell, Prostate, Hormonal Therapy, Epithelial Mesenchymal Transition

\section{Introduction}

An epithelial to mesenchymal transition (EMT) is thought to be a biologic 
process that allows a polarized epithelial cell to undergo multiple biochemical changes that enable it to assume a mesenchymal cell phenotype, including enhanced migratory capacity, invasiveness, elevated resistance to apoptosis and increased production of extracellular matrix components [1]. The role of EMT is thought to a process of tissue repair by some pathological stress, inflammation and injury. The EMT is also believed to be a critical step in the progression of cancers from both the pre-invasive to invasive state, and from organ confined to metastatic disease [2]. At prostatic tissue, EMT is reported to play an important role in progression of benign hyperplastic change [3] [4], carcinogenesis, acquiring apoptotic tolerance [5], neuroendocrine differentiation and chemotherapy resistance [6]. Among these roles, EMT at the first hormonal therapy is thought to play an essential role in obtaining castrate resistance for hormone naïve prostate cancer as well as benign prostatic tissues [7]. So we studied EMT of prostatic cells after exposure of various hormonal agents (degarelix/LHRH antagonist as androgen deprivation, chlormadinone acetate as short course hormone and dutasteride/5-alpha-reductase inhibitor as a long-period hormonal use) using transurethral resection (TUR) of prostate for benign prostatic hyperplasia specimens.

\section{Materials and Methods}

TUR specimens without hormonal use (4 cases), specimens two weeks after initial use of degarelix (3 cases), specimens after three weeks use of chlormadinone acetate (CMA) (9 cases) and specimens after average six months use of dutasteride (3 cases) were studied using Hematoxylin and Eosin (HE) and immunohistochemical staining with prostate specific antigen (PSA), reported prostatic stem cell markers [3] such as CD44 (Gene Tex Hsinchu, Taiwan), CD117 (c-kit) (abcam Cambridge, England), CD133 (ENOGENE NY, USA) and Vimentin (Santa cruz Dallas USA). One of the microscopic preparations from each surgical specimens were presented for immunohistochemical analysis. Results were compared with control (specimens without hormone). Non-specific staining by artefact presumably caused by TUR procedure was excluded. Usual immunohistochemical method was used for these studies [8]. The project was evaluated and approved by institutional internal review board and patients were explained and approved on the use of their TUR specimens. The use and using period of these drugs were appropriate for preoperative medication of TUR for benign prostatic hyperplasia (CMA and dutasteride), or neo-adjuvant hormonal therapy (degarelix) for prostate cancer and TUR for irradiation.

\section{Results}

Stained results are summarized on a Table 1. On HE staining, specimens treated with CMA showed acinar dilatation and atrophy of glandular cells. Specimens treated with dutasteride showed marked decrease of gland and increase of fibromuscular tissue. Specimens treated with degarelix showed decrease of 
Table 1. Stained results.

\begin{tabular}{|c|c|c|c|c|c|c|}
\hline & $\mathrm{n}$ & $\mathrm{HE}$ & PSA & CD44 & $\begin{array}{l}\text { CD117 } \\
\text { CD133 }\end{array}$ & Vimentin \\
\hline Control & 4 & & luminal cells & basal cell & minimum & $\begin{array}{l}\text { interstitial } \\
\text { cells }\end{array}$ \\
\hline CMA & 9 & $\begin{array}{c}\text { acinar } \\
\text { dilatation, basal } \\
\text { cell elongation }\end{array}$ & luminal cells & $\begin{array}{l}\text { elongated } \\
\text { basal cells to } \\
\text { luminal cells }\end{array}$ & minimum & $\begin{array}{l}\text { interstitial } \\
\text { cells }\end{array}$ \\
\hline Degarelix & 3 & $\begin{array}{c}\text { decreased } \\
\text { glandular cells }\end{array}$ & luminal cells & basal cell & minimum & $\begin{array}{l}\text { interstitial } \\
\text { cells }\end{array}$ \\
\hline Dutasteride & 3 & atrophic gland & luminal cells & basal cell & minimum & $\begin{array}{l}\text { interstitial } \\
\text { cells }\end{array}$ \\
\hline
\end{tabular}

glandular cells. Specimens from 6 months dutasteride use showed marked atrophic glandular structures, though other specimens did not. Among the stem cell markers, only CD44 showed different staining results between control and post-hormonal specimens. Only small numbers of infiltrating cells in interstitial tissue indicated CD 117 and CD 133 positive in all specimens, and Vimentin was stained all interstitial tissues, indicating not informative of these results. Representative results of HE, PSA and CD44 staining in control (Figures 1(a)-(c)), CMA (Figures 2(a)-(c)), degarelix (Figures 3(a)-(c)) and dutasteride (Figures $4(\mathrm{a})-(\mathrm{c}))$ use are indicated.

PSA was stained almost equally for all specimens at glandular cells.

Small numbers of basal cells were stained by CD44 antibody in control specimens (magnified figure in blue box). Specimens after using degarelix and dutasteride indicated more apparent CD 44 staining at basal cells and small numbers of glandular cells. CD 44 was most apparently stained at basal cells and also at glandular cells in the specimens using CMA, suggesting stem cell transformation by EMT.

\section{Discussion}

EMT is reported to play a pivotal role not only for prostate organ development in embryogenesis but also for benign hyperplastic change and malignant tumorigenesis [4] [9]. Androgen deprivation causes EMT for both normal and malignant prostatic gland [10]. EMT induced by castration changes prostatic luminal cells into cancer stem cells (CSCs), and helps these cells to obtain apoptosis resistance by castration [5]. The prostate consists of three cell types. Basal cells are relatively undifferentiated, androgen-independent cell, expressing CK5, 14 and CD44, but low or no expression of androgen receptors (AR) and PSA. Secretory luminal, glandular epithelial cells are mature differentiated cells expressing AR and PSA, however CD44 are usually negative. The neuroendocrine cells appear to be androgen independent and differentiated cells expressing chromogranins without AR or PSA [11]. Prostate stem cells are reported to express CD44 and CD133, and prostate cancer stem cells also express these markers [4] [11]. Prostate stem cells and some of prostate cancers are believed to originating in basal 


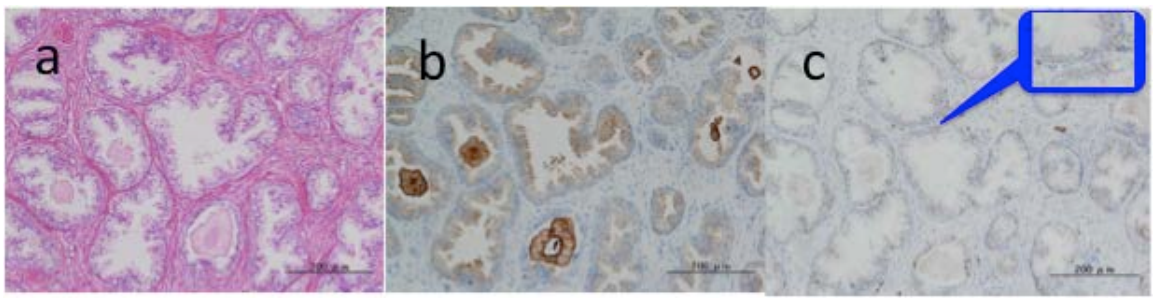

Figure 1. Control specimens stained with HE (a), PSA (b) and CD 44 (c), reduced from 10×. Magnified figure is indicated in blue box 40×. PSA was positive in luminal cells (b), and only basal cells stained by CD44 (c).

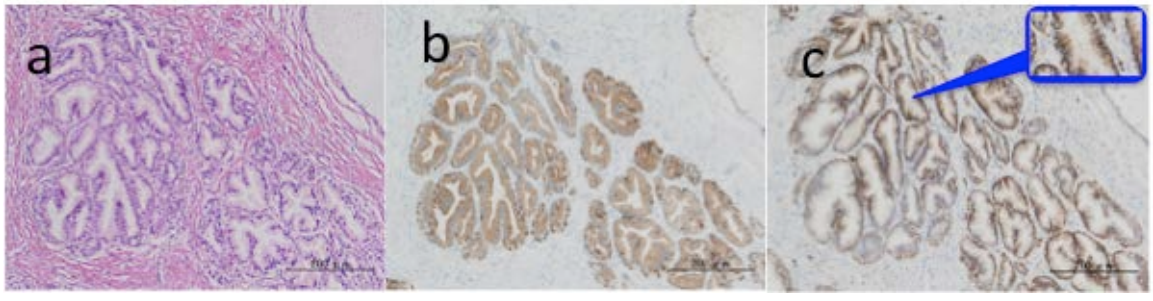

Figure 2. Specimens after using CMA stained with HE (a), PSA (b) and CD 44 (c), reduced from $10 \times$. Magnified figure is indicated in blue box 40×. PSA was clearly positive in luminal cells (b); Elongation of basal cell and prominent CD44 positivity were noted (c).

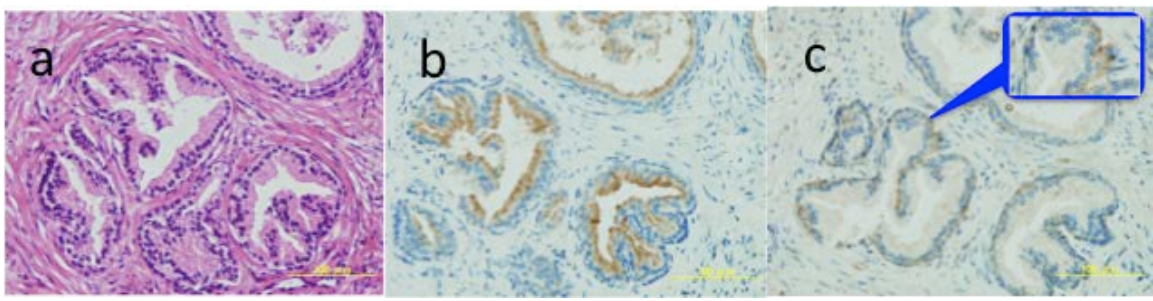

Figure 3. Specimens after using degarelix stained with HE (a); PSA (b) and CD 44 (c),

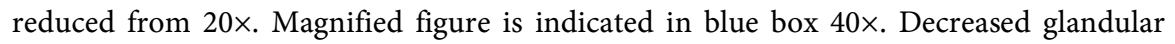
cells were noted (upper part). PSA was positive in luminal cells (b); CD44 positivity was not prominent compared to CMA use (c).

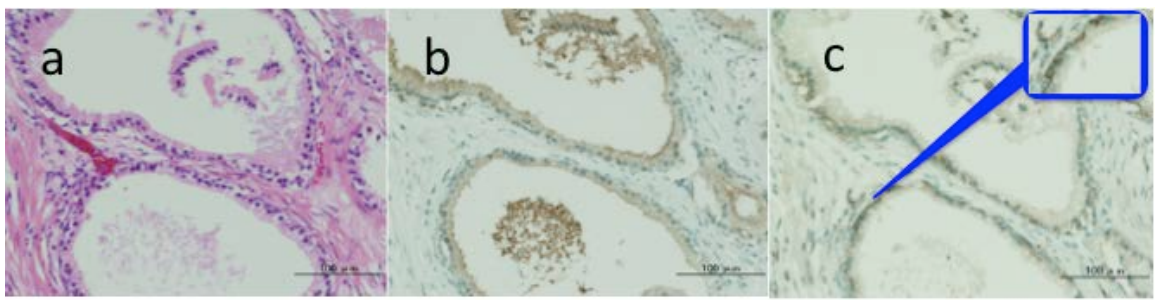

Figure 4. Specimens after using 6 months of dutasteride stained with HE (a), PSA (b) and CD 44 (c), reduced from 20×. Magnified figure is indicated in blue box 40×. Atrophic glandular structures and dilated lumen were noted. PSA was positive in atrophic luminal cells (b). CD44 positivity was not prominent (c).

cells [4] [12]. Toivanen et al. reported that repair of prostate epithelial luminal cells by basal cells, those were damaged following castration in mice. And they also mentioned that this basal-to-luminal differentiation in prostate epithelial 
repair might contribute to prostatic cancer development and castration resistance [13]. Recent report also support that prostatic basal cells play a pivotal role as a prostatic stem cell and tumorigenesis [14] [15]. These reports support our results; CD 44 positive basal to luminal differentiation cells were prominent in CMA treated specimens as a part of luminal cell repair damaged by CMA in vivo. Furthermore, our results might show stem cell differentiation and acquirement of apoptosis resistance by epithelial to mesenchymal transition by basal cells as well. Our results clearly indicated that luminal cell turned to positive for CD44 after using CMA, however CD 117 and CD133, those were also reported to be the stem cell marker, did not show positive in these condition. Wei et al. reported that CD133 did not enrich for stem cell activity in vivo in adult mouse prostates [16]. That may be consistent with our results. Meanwhile CD44 is important as malignant stem cell marker [17], and CD44 positive cell was reported to play a crucial role for acquiring metastatic potential in prostate cancer [18]. The possibility of molecular targeting therapy, inhibiting the activation of CD44 using mi-RNA was also reported [19].

Our results suggested that three weeks administration of CMA showed one of a model of stem cell transformation of human prostatic cells in vivo.

Elongation of basal cells and increased sensitivity to CD44 in glandular cells, especially treated with CMA, were thought to the result of EMT of prostatic glandular cells. Six months use of dutasteride might be long enough to alter the structure of prostatic tissue, and degarelix had strong apoptotic activity to prostate cells even in a short period.

\section{Conflict of Interests}

The authors declare that there is no conflict of interests on this project.

\section{References}

[1] Kalluri, R. and Weinberg, R.A. (2009) The Basics of Epithelial-Mesenchymal Transition. Journal of Clinical Investigation, 119, 1420-1428.

https://doi.org/10.1172/JCI39104

[2] Lima, J.F., Nofech-Mozes, S., Bayani, J. and Bartlett, J.M.S. (2016) EMT in Breast Carcinoma-A Review. Journal of Clinical Medicine, 5, 65. https://doi.org/10.3390/jcm5070065

[3] Alonso-Magdalena, P., Brossner, C., Reiner, A., Cheng, G., Sugiyama, N., Warner, M. and Gustafsson, J.A. (2009) A Role for Epithelial-Mesenchymal Transition in the Etiology of Benign Prostatic Hyperplasia. Proceedings of the National Academy of Sciences of the United States of America, 106, 2859-2863.

https://doi.org/10.1073/pnas.0812666106

[4] Prajapati, A., et al. (2013) Prostate Stem Cells in the Development of Benign Prostate Hyperplasia and Prostate Cancer: Emerging Role and Concepts. BioMed Research International, 2013, Article ID: 107954.

[5] Li, P., et al. (2014) Contributions of Epithelial-Mesenchymal Transition and Cancer Stem Cells to the Development of Castration Resistance of Prostate Cancer. Molecular Cancer, 13, 55. https://doi.org/10.1186/1476-4598-13-55 
[6] Marin-Aguilera, M., Codony-Servat, J., Reig, O., et al. (2014) Epithelial-to-Mesenchymal Transition Mediates Docetaxel Resistance and High Risk of Relapse in Prostate Cancer. Molecular Cancer Therapeutics, 13, 1270-1284.

[7] Shi, X., Gipp, J., Dries, M. and Bushman, W. (2014) Prostate Progenitor Cells Proliferation in Response to Castration. Stem Cell Research, 13, 154-163. https://doi.org/10.1016/j.scr.2014.04.005

[8] Kim, S.W., Roh, J. and Park, C.S. (2016) Immunohistochemistry for Pathologists: Protocols, Pitfalls, and Tips. Journal of Pathology and Translational Medicine, 50, 411-418. https://doi.org/10.4132/jptm.2016.08.08

[9] Grant, C.M. and Kyprianou, N. (2013) Epithelial Mesenchymal Transition (EMT) in Prostate Growth and Tumor Progression. Translational Andrology and Urology, 2, 202-211.

[10] Sun, Y., Wang, B.-E., Leong, K.G., Yue, P., Li, L., Jhunjhunwala, S., Chen, D., et al. (2011) Androgen Deprivation Causes Epithelial-Mesenchymal Transition in the Prostate: Implications for Androgen-Deprivation Therapy. Cancer Research, 7, 527-536.

[11] Moltzahn, F. and Thalmann, G.N. (2013) Cancer Stem Cells in Prostate Cancer. Translational Andrology and Urology, 2, 242-253.

[12] Stoyanova, T., Cooper, A.R., Drake, J.M., Liu, X., Armstrong, A.J., Pienta, K.J., et al. (2013) Ptostate Cancer Originating in Basal Cells Progress to Adenocarcinoma Propagated by Luminal-Like Cells. Proceedings of the National Academy of Sciences of the United States of America, 110, 20111-20116. https://doi.org/10.1073/pnas.1320565110

[13] Toivanen, R., Mohan, A. and Shen, M.M. (2016) Basal Progenitors Contribute to Repair of the Prostate Epithelium Following Induced Luminal Anoikis. Stem Cell Reports, 6, 660-667. https://doi.org/10.1016/j.stemcr.2016.03.007

[14] Brocqueville, G., Chmelar, R.S., Bauderlique-Le Roy, H., Deruy, E., Tian, L., Vessella, R.L., Greenberg, N.M., Rohrschneider, L.R. and Bourette, R.P. (2016) s-SHIP Expression Identifies a Subset of Murine Basal Prostate Cells as Neonatal Stem Cells. Oncotarget, 7, 29228-29244.

[15] Kwon, O.J., Zhang, B., Zhang, L. and Xin, L. (2016) High Diet Promotes Prostatic Basal-to-Luminal Differentiation and Accelerates Initiation of Prostate Epithelial Hyperplasia Originated from Basal Cells. Stem Cell Research, 16, 682-691. https://doi.org/10.1016/j.scr.2016.04.009

[16] Wei, X., Orjalo, A.V. and Xin, L. (2016) CD133 Does Not Enrich for the Stem Cell Activity in vivo in Adult Mouse Prostates. Stem Cell Research, 16, 597-606. https://doi.org/10.1016/j.scr.2016.03.003

[17] Xu, H., Tian, Y., Yuan, X., Wu, H., Liu, Q., Pestell, R.G. and Wu, K. (2015) The Role of CD44 in Epithelial-Mesenchymal Transition and Cancer Development. OncoTargets and Therapy, 8, 3783-3792.

[18] Shang, Z., Cai, Q., Zhang, M., Zhu, S., Ma, Y., Sun, L., Jiang, N., et al. (2014) A Switch from CD $44^{+}$Cell to EMT Cell Drives the Metastasis of Prostate Cancer. Oncotarget, 6, 1202-1216.

[19] Liu, C., Kelnar, K., Liu, B., Chen, X., Calhoun-Davis, T., Li, H., et al. (2011) Identification of miR-34a as a Potent Inhibitor of Prostate Cancer Progenitor Cells and Metastasis by Directory Repressing CD44. Nature Medicine, 17, 211-215. https://doi.org/10.1038/nm.2284 